\title{
Brain damage in dogs immediately following pulsatile and non-pulsatile blood flows in extracorporeal circulation
}

\author{
J. M. SANDERSON, G. WRIGHT, and F. W. SIMS \\ W. E. Dunn Unit of Cardiology, Biology Department, University of Keele, Staffordshire
}

\begin{abstract}
The brains of dogs subjected to total cardiac bypass were examined for early signs of ischaemic nerve cell changes. Diffuse nerve cell changes were found immediately following two- and threehour non-pulsatile perfusions but not following pulsatile perfusions of the same durations. The nerve cell changes found in the brains were acute cell swelling and early ischaemic cell change. Acute cell swelling was found only in the cerebellar Purkinje cells. Ischaemic cell change was found in several regions of the brain but the cerebral cortex and cerebellar Purkinje cells were most frequently affected. Diffuse nerve cell changes are attributed to non-pulsatile blood flow but some complicating factors are recognized.

Focal lesions found in three brains may have been due to embolism by blood cell aggregates and/or gas microbubbles.
\end{abstract}

Roller pumps are currently in general use for the production of extracorporeal circulation during open-heart surgery. Their remarkable efficiency and easy control have been a hindrance to the development of alternative types of pump. However, an increasing volume of evidence supports the view that pumps producing pulsatile blood flow would provide more efficient tissue perfusion than roller pumps producing ripple (non-pulsatile) blood flow. We have performed experiments to test this view using brain damage as a criterion for assessing tissue perfusion.

\section{MATERIALS AND METHODS}

General anaesthesia was induced in 20 beagle and harrier dogs, $6.5-20.0 \mathrm{~kg}$ body weight, by intravenous injection of $0.25-0.5 \mathrm{~g}$ of sodium thiopentone (Intraval). After endotracheal intubation the dogs were artificially ventilated by a Palmer Ideal respirator delivering 200$400 \mathrm{ml} / \mathrm{stroke}$ at $16 \mathrm{strokes} / \mathrm{min}$, and light anaesthesia was maintained with a variable mixture of $0.0-2.0 \%$ halothane (Fluothane) in nitrous oxide and oxygen.

A modified Drew (1961) technique was used to establish an extracorporeal circulation, employing either occlusive DeBakey roller pumps for nonpulsatile blood flows (DeBakey, 1934) or the MortonKeele prototype pulsatile pump (Sanderson $e t$ al.) with Harvard remote diaphragm heads. The circuit tubing was $6.0 \mathrm{~mm}$ internal diameter polyvinyl chloride (PVC). The reservoirs were also PVC and each reservoir had a capacity of $300 \mathrm{ml}$. The heat exchanger consisted of four stainless steel tubes each $1.5 \mathrm{~m}$ in length and with an internal diameter of $6.0 \mathrm{~mm}$ mounted in a copper water jacket. The heat exchanger was placed in the left atrial return instead of being in the delivery line from the left pump. This translocation was introduced to reduce damping of the pulse delivered by the pulsatile pump.

All of the cannulae were made of stainless steel. The atria were drained through $6.0 \mathrm{~mm}$ internal diameter fenestrated cannulae. The internal diameters of the arterial cannulae were 4.0 or $5.0 \mathrm{~mm}$ for the pulmonary artery, $2.5,3.0$ or $3.5 \mathrm{~mm}$ for the femoral artery, and $4.0,5.0$ or $6.0 \mathrm{~mm}$ for the proximal aorta, depending upon the diameter of the lumen of the artery.

The extracorporeal circuit was primed with $1,300 \mathrm{ml}$ dog blood; $10 \mathrm{ml} 10 \%$ low molecular weight dextran in $0.9 \%$ sodium chloride (Rheomacrodex) and $4 \mathrm{ml}$ $10 \%$ mannitol $/ \mathrm{kg}$ of body weight; plus $4 \mathrm{ml} 20 \%$ sodium bicarbonate, 2,500 international units heparin, and $3 \mathrm{ml} 20 \%$ calcium chloride $/ 500 \mathrm{ml}$ priming fluid.

Using clean surgical techniques, a median sternotomy was performed to permit cannulation of the right and left atria and the pulmonary artery. For non-pulsatile flow, the aorta was retrogradely perfused through the left femoral artery. The proximal aorta was cannulated for pulsatile flow because earlier experiments had shown that the pulse is severely damped when perfusing through narrow cannulae such as those necessary for femoral artery inputs.

A standard pulse frequency of $100 / \mathrm{min}$ was employed for pulsatile experiments. Pulsatile blood flow rates were measured by a Medelec electromagnetic 
flowmeter placed in the left arterial line. Non-pulsatile blood flow rates were measured by the frequency of roller revolutions. Both measurements were calibrated with saline before starting each perfusion. Maximal blood flows were limited by venous returns to 50-75 $\mathrm{ml} / \mathrm{kg}$ of body weight per minute. When flows had been stabilized, the heart was fibrillated with direct current shocks and maintained in a state of fibrillation for one, two or three hours of perfusion with the oesophageal temperature at $29 \cdot 0-31 \cdot 0^{\circ} \mathrm{C}$ (Table I). Rewarming was begun during the last 20 minutes of perfusion to raise the oesophageal temperature to $29 \cdot 9-35 \cdot 6^{\circ} \mathrm{C}$ before defibrillation.

\section{T A B L E I}

EXPERIMENTAL DATA FOR PULSATILE AND NONPULSATILE NON-RECOVERY EXPERIMENTS

\begin{tabular}{|c|c|c|c|c|c|c|}
\hline $\begin{array}{c}\text { Experi- } \\
\text { ment } \\
\text { No. }{ }^{1}\end{array}$ & $\begin{array}{c}\text { Body } \\
\text { Weight } \\
(\mathbf{k g})\end{array}$ & $\begin{array}{c}\text { Brain } \\
\text { Weight } \\
\text { (g) }\end{array}$ & $\begin{array}{l}\text { Grade of } \\
\text { Fixation }\end{array}$ & $\begin{array}{l}\text { Total } \\
\text { ICC }\end{array}$ & $\begin{array}{l}\text { Total } \\
\text { ACS }\end{array}$ & $\begin{array}{l}\text { Perfusion } \\
\text { Procedure }\end{array}$ \\
\hline $\begin{array}{l}1 / 78 \\
2 / 100 \\
3 / 104 \\
4 / 107 \\
5 / 118 \\
6 / 83 \\
7 / 123 \\
8 / 124 \\
9 / 120 \\
10 / 92 \\
11 / 93 \\
12 / 111 \\
13 / 127 \\
14 / 84 \\
15 / 85 \\
16 / 91 \\
17 / 94 \\
18 / 112 \\
19 / 122 \\
20 / 149\end{array}$ & $\begin{array}{r}13 \cdot 0 \\
10 \cdot 8 \\
9 \cdot 5 \\
11 \cdot 7 \\
12 \cdot 7 \\
10 \cdot 8 \\
7 \cdot 2 \\
14 \cdot 9 \\
9 \cdot 5 \\
20 \cdot 0 \\
12 \cdot 7 \\
6 \cdot 5 \\
15 \cdot 0 \\
7 \cdot 3 \\
11 \cdot 0 \\
9 \cdot 9 \\
13 \cdot 1 \\
6 \cdot 5 \\
12 \cdot 7 \\
10 \cdot 8\end{array}$ & $\begin{array}{l}\overline{84 \cdot 9} \\
70 \cdot 7 \\
77 \cdot 4 \\
89 \cdot 5 \\
\overline{72 \cdot 4} \\
81 \cdot 8 \\
80 \cdot 7 \\
\overline{89 \cdot 6} \\
75 \cdot 0 \\
80 \cdot 7 \\
- \\
- \\
79 \cdot 5 \\
73 \cdot 4 \\
83 \cdot 2 \\
82 \cdot 6\end{array}$ & $\begin{array}{l}2 \\
1 \\
1 \\
2 \\
1 \\
2 \\
1 \\
2 \\
3 \\
2 \\
2 \\
1 \\
2 \\
2 \\
4 \\
4 \\
3 \\
1 \\
4 \\
1\end{array}$ & $\begin{array}{r}0 \\
0 \\
0 \\
0 \\
0 \\
1 \\
0 \\
0 \\
15 \\
0 \\
0 \\
0 \\
0 \\
3 \\
18 \\
36 \\
1 \\
10 \\
13 \\
5\end{array}$ & $\begin{array}{l}0 \\
0 \\
0 \\
0 \\
0 \\
0 \\
0 \\
0 \\
3 \\
0 \\
0 \\
0 \\
0 \\
0 \\
0 \\
3 \\
0 \\
3 \\
0 \\
0\end{array}$ & $\begin{array}{l}\text { Control } \\
\text { Control } \\
\text { Control } \\
\text { Control } \\
3 \mathrm{hr} \text { anaesthesia } \\
1 \mathrm{hr} \text { pulsatile } \\
1 \mathrm{hr} \text { non-pulsatile } \\
2 \mathrm{hr} \text { pulsatile } \\
2 \mathrm{hr} \text { non-pulsatile } \\
3 \mathrm{hr} \text { pulsatile } \\
3 \mathrm{hr} \text { pulsatile } \\
3 \mathrm{hr} \text { pulsatile } \\
3 \mathrm{hr} \text { pulsatile } \\
3 \mathrm{hr} \text { non-pulsatile } \\
3 \mathrm{hr} \text { non-pulsatile } \\
3 \mathrm{hr} \text { non-pulsatile } \\
3 \mathrm{hr} \text { non-pulsatile } \\
3 \mathrm{hr} \text { non-pulsatile } \\
3 \mathrm{hr} \text { non-pulsatile } \\
3 \mathrm{hr} \text { non-pulsatile }\end{array}$ \\
\hline
\end{tabular}

The second number refers to the Keele series

ICC $=$ ischaemic cell change

ACS $=$ acute cell swelling

During perfusion, the fluid levels in the reservoirs were kept constant by homologous blood infusions. One femoral artery was exposed and a no. 6 French side-eye pressure catheter was passed up to the lower abdominal aorta for the measurement of arterial blood pressure (AP). The catheter was connected by stiff polythene tubing to a $0-300 \mathrm{mmHg}$ strain-gauge pressure transducer with an input to an Elema-Schönander Mingograph multichannel pen recorder. Heparin (300 i.u./kg) was administered before the introduction of the femoral artery pressure catheter. Venous blood pressure (VP) was measured by a saline manometer connected to a 17-gauge intravenous cannula passing through the skin into the right cephalic vein. Both AP and VP were recorded at 10-minute intervals before and during extracorporeal circulation. The oesophageal temperature and electrocardiograph were continuously monitored. Blood samples were obtained from the femoral artery before perfusion and from a two-way sampling tap in the left atrial drain during perfusion for estimates of arterial blood carbon dioxide tension $\left(\mathrm{PACO}_{2}\right), \mathrm{pH}$, standard bicarbonate, and base excess using Astrup micro-equipment. Base deficits were corrected with sodium bicarbonate. After defibrillation the animals were perfuse-fixed by the technique of Wright and Sanderson (1970).

Five dogs served as controls; four of these were subjected to thoracotomy under general anaesthesia and immediately perfuse-fixed. The fifth dog was maintained under general anaesthesia for three hours with the thoracic and pericardial cavities open before perfusion-fixation.

\section{RESULTS}

Typical abdominal aorta blood pressure records are shown in Figure 1. The pulsatile pump produces a pulse profile that closely resembles the normal pressure pulse generated in the abdominal aorta by contraction of the left ventricle. A rapid upstroke is thought to be critical. In these experiments the upstroke time was within the range $0.08-0.15$ second at 100 pump strokes/minute. The diastolic phase of the pressure pulse is probably determined by the elastic properties of the walls of blood vessels, especially those of elastic arteries and arterioles. Pulse pressures were within the range $25-90 \mathrm{mmHg}$. Roller pump action is characterized by a pressure plateau near the mean value and sudden low-amplitude pressure reductions as each roller leaves the arterial end of the cuff. The range of pulse pressures is normally $2-15 \mathrm{mmHg}$ but occasionally reaches $30 \mathrm{mmHg}$ in very small dogs. The non-pulsatile 'pulse' contour has a prolonged upstroke phase occupying about $80 \%$ of the total cycle. During the remaining $20 \%$ of the cycle a sharp reduction in blood pressure is followed by a recovery of approximately equal amplitude.

Table I contains a list of the experiments performed. Body weight was determined before each experiment. Brain weight is the weight of the fixed brain sectioned through the olfactory bulbs and between spinal cord segments 2 and 3 . The grade of fixation was assessed while the tissue blocks were being prepared for processing. The following scheme was used:

$\begin{array}{cl}\begin{array}{c}\text { Grade of } \\ \text { fixation } \\ 1\end{array} & \begin{array}{l}\text { Quality of fixation } \\ \text { Excellent-tissue uniformly hard and } \\ \text { white }\end{array} \\ 2 & \begin{array}{l}\text { Very good-occasional blood vessel } \\ \text { contains blood, but tissues uniformly } \\ \text { hard and white } \\ \text { Good-slight pinkness in some regions, } \\ \text { but tissue uniformly hard }\end{array} \\ 3 & \begin{array}{l}\text { Patchy-regions of soft, pink tissue } \\ \text { Poor-generally soft and pink tissue in } \\ \text { most regions of the brain }\end{array}\end{array}$




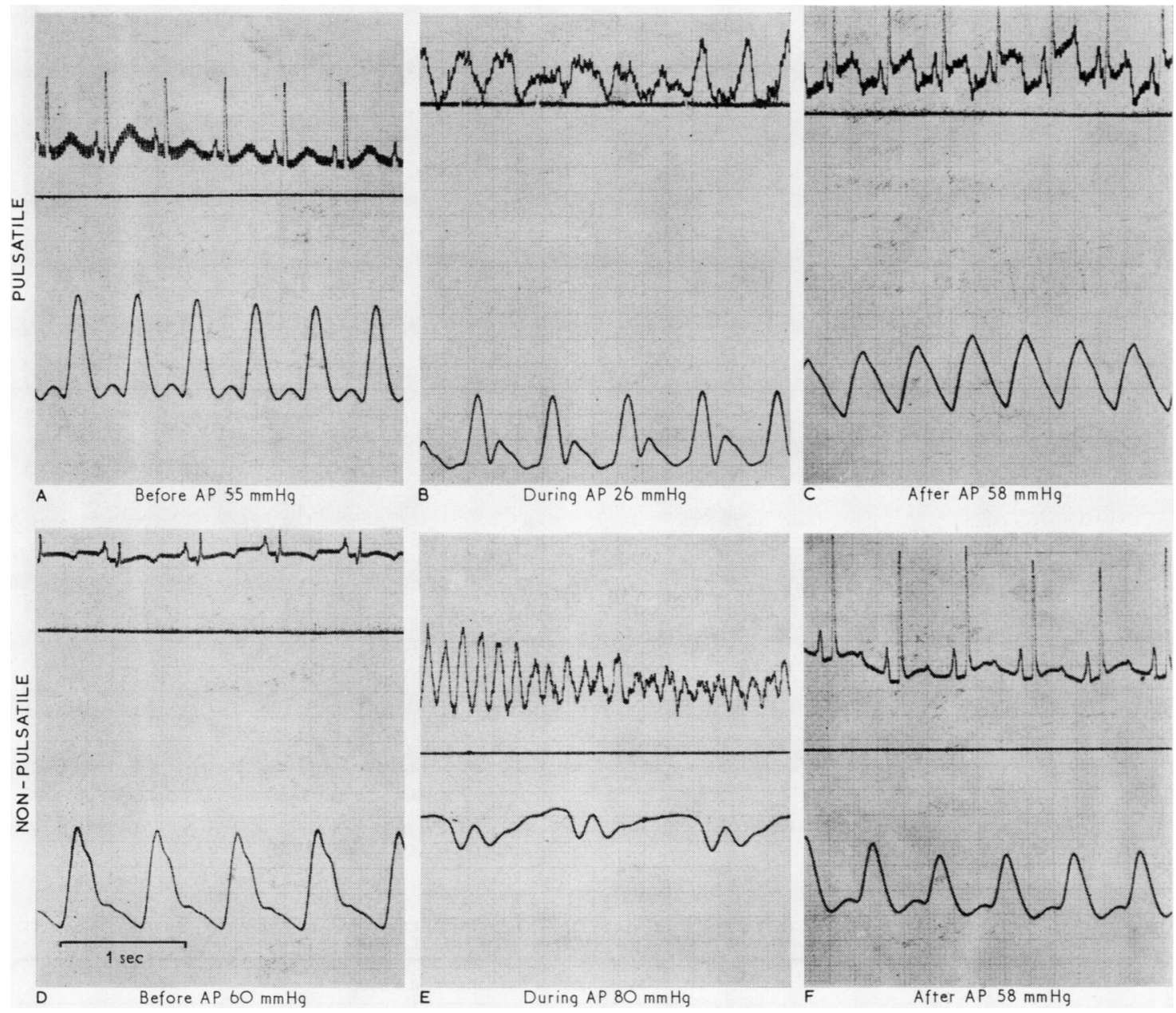

FIG. 1. Electrocardiograms and abdominal aorta blood pressure records obtained before, during, and after extracorporeal circulation with pulsatile (above) and non-pulsatile (below) flows.

Grade 5 brains were rejected. Total ischaemic cell change (ICC) and total acute cell swelling (ACS) were derived by the vertical addition of columns in Tables II and III in which the histological results are listed. The method of quantifying nerve cell changes was taken from Brown and Brierley (1968). The hypophysis is not included in the tables because no cell damage was observed in either the neurohypophysis or adenohypophysis in any of the experiments.

No nerve cell changes were found in any of the five control dogs including the dog maintained under anaesthesia for three hours (Figs 2 and 3). In the brains of experimental animals, nerve cell changes were of two types-diffuse and focal.
Where nerve cells undergoing pathological changes were randomly distributed over a wide area, they were categorized as diffuse cell changes. Focal lesions were small and well defined. They were either oval or wedge-shaped, and the widest dimension never exceeded $4.0 \mathrm{~mm}$. Diffuse cell changes were further classified as ICC and ACS. Microvacuolation, homogenizing cell change, and ischaemic cell change with incrustations were not found as diffuse changes.

Ischaemic nerve cell changes were found in all cases after two or three hours of non-pulsatile perfusion but not after pulsatile perfusions of the same durations (Table II). The severity of ICC varied from mild shrinkage of the perikaryon 


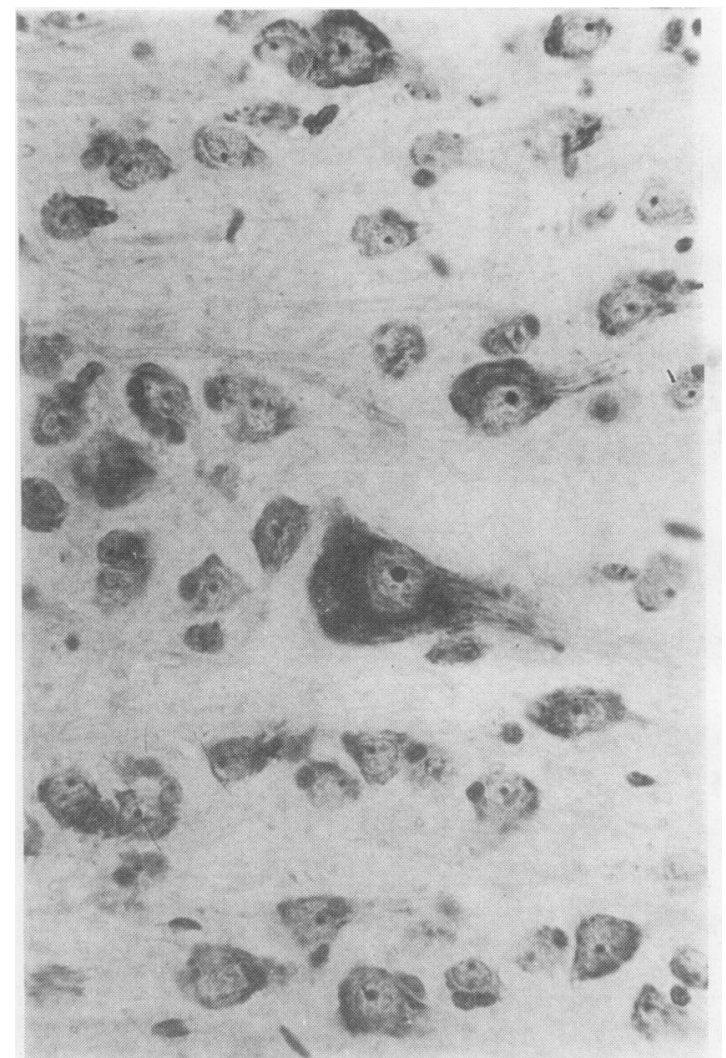

FIG. 2. Normal dog cerebral cortex. Control (luxol fast blue and cresyl fast violet $\times 400$ ).

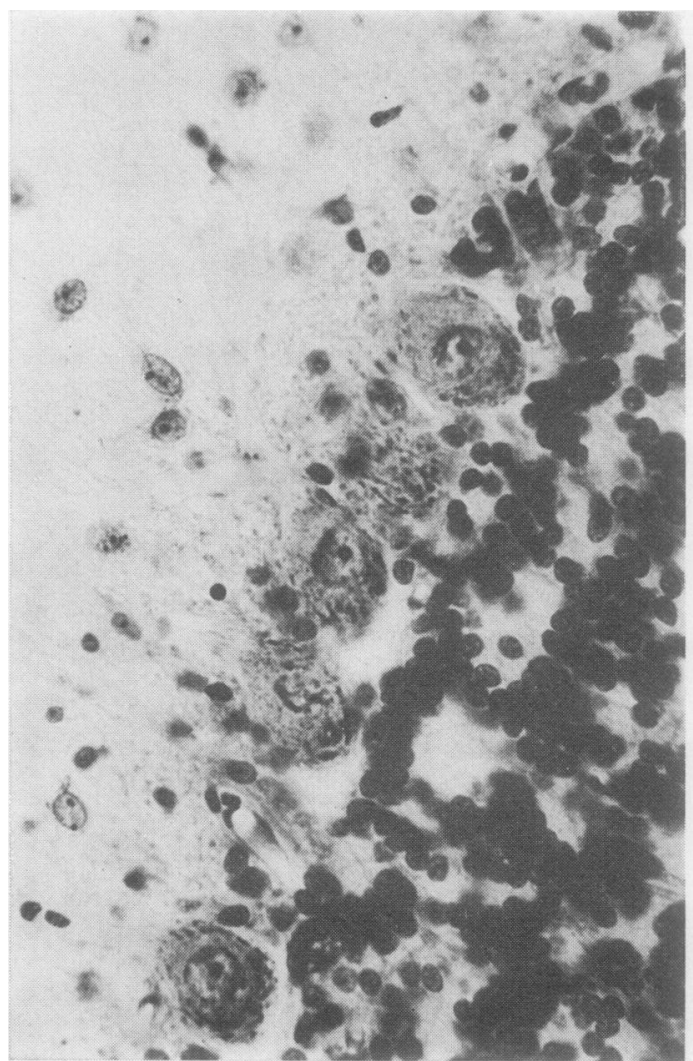

FIG. 3. Normal dog cerebellar cortex. Control (luxol fast blue and cresyl fast violet $\times 400$ ).

T A B L E I I

ASSESSMENT OF ISCHAEMIC CELL CHANGE IN BRAINS OF DOGS IMMEDIATELY FOLLOWING PULSATILE AND NON-PULSATILE EXTRACORPOREAL CIRCULATION

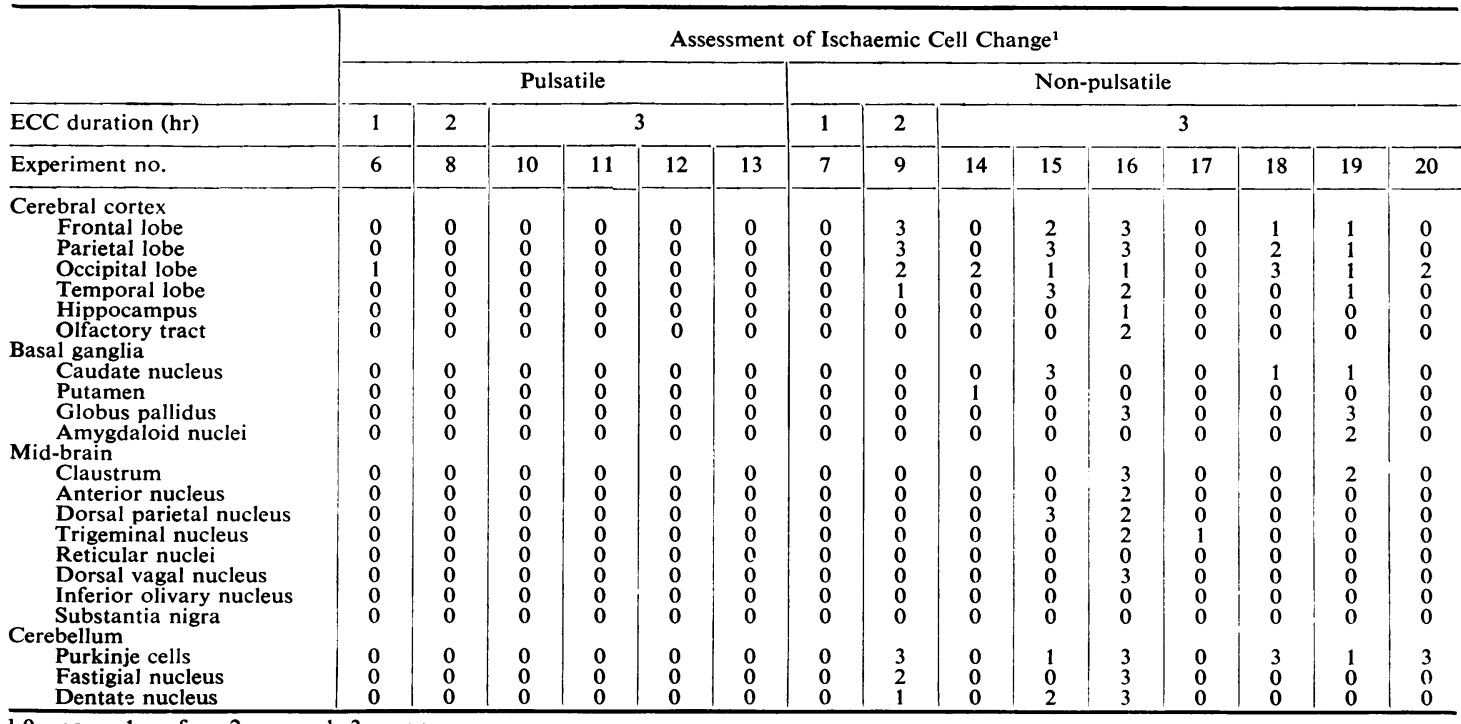

0 =none; 1 =a few; 2 =several; 3 =many. 


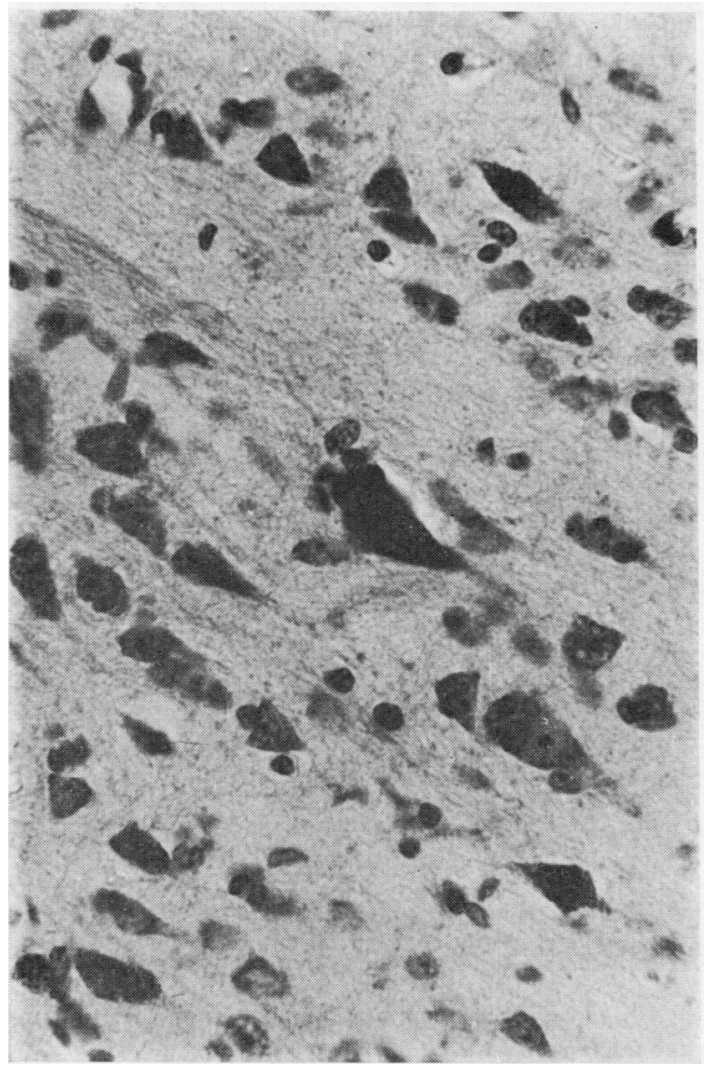

FIG. 4. Mild ischaemic cell change in dog cerebral cortex; 3 hours' non-pulsatile flow (luxol fast blue and cresyl fast violet $\times 400$ ).

(Fig. 4) to marked shrinkage of both the perikaryon and nucleus and corkscrew deformation of the cell processes (Fig. 5). Many of the capillaries in regions of ICC had collapsed and had developed prominent perivascular spaces. The regions most frequently affected by ICC were the cerebral cortex and cerebellar Purkinje cells. The boundary zones of the major cerebral arteries were affected more often than other regions of the cerebral cortex, and pyramidal nerve cells were affected more often than non-pyramidal nerve cells. Layers 3 and 5 of the cerebral cortex were selectively damaged in two of the three-hour non-pulsatile perfusions.

Purkinje cells undergoing ACS were found after one two-hour and two three-hour non-pulsatile perfusions (Table III and Fig. 6). These cells had grossly swollen perikarya due to the formation of a wide peripheral clear space in the cytoplasm Care was taken not to confuse this intracellular space with the space that commonly forms around

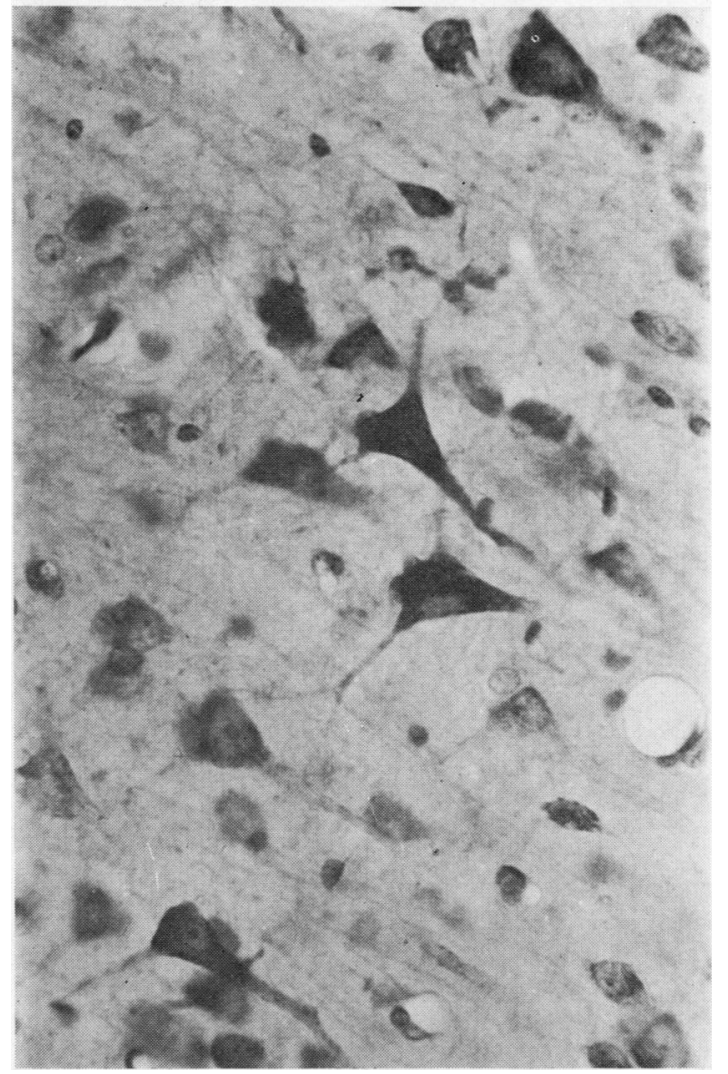

FIG. 5. Severe ischaemic cell change in dog cerebral cortex; 3 hours' non-pulsatile flow (luxol fast blue and cresyl fast violet $\times 400)$.

nerve cells undergoing ICC. It was usual to find focal regions of rarefied neuropil, $10-50 \mu$ in diameter, in the molecular layer of the cerebellum close to swollen Purkinje cells. Regions of rarefied neuropil were most conspicuous in sections stained with H-PAS (Fig. 7).

Isolated focal lesions were found in the brain after one two-hour non-pulsatile and after two three-hour pulsatile perfusions (Figs 8 and 9). These lesions were characterized by focal staining pallor and minimal degeneration of the nerve cells within the lesion. Nerve cells exhibiting ICC were present in these lesions along with nerve cells that stained very palely and appeared to be deficient in cytoplasmic organelles and nuclear chromatin. Many nerve cell processes appeared to be swollen and some oligodendrocytes had dark-staining nuclei with swollen pale-staining perikarya. Nerve cells and glia close to the lesion appeared to be normal. 


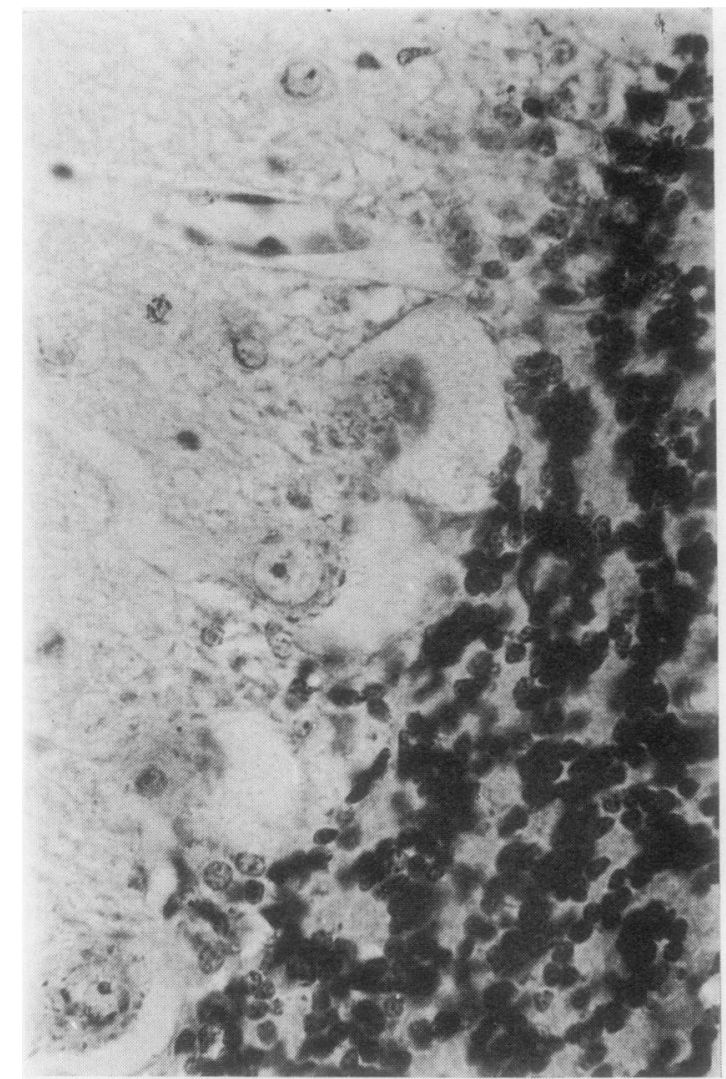

FIG. 6. Acute cell swelling of Purkinje cells in dog cerebellar cortex; 3 hours' non-pulsatile flow (luxol fast blue and cresyl fast violet $\times 400$ ).

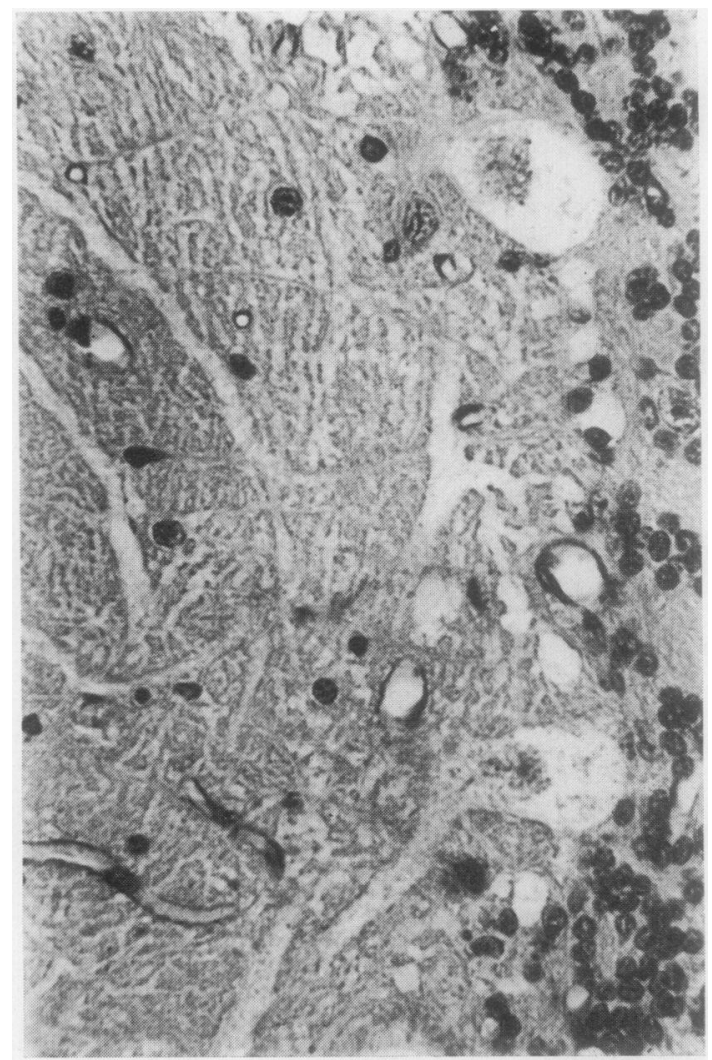

FIG. 7. Rarefied neuropil adjacent to Purkinje cells undergoing acute cell swelling in dog cerebellar cortex; 3 hours, non-pulsatile flow (haemalum and periodic acid schiff $\times 400$ ).

T A B L E I I I

ASSESSMENT OF ACUTE CELL SWELLING IN BRAINS OF DOGS IMMEDIATELY FOLLOWING PULSATILE AND NON-PULSATILE EXTRACORPOREAL CIRCULATION

\begin{tabular}{|c|c|c|c|c|c|c|c|c|c|c|c|c|c|c|c|}
\hline \multirow[b]{3}{*}{ ECC duration (hr) } & \multicolumn{15}{|c|}{ Assessment of Acute Cell Swelling ${ }^{1}$} \\
\hline & \multicolumn{6}{|c|}{ Pulsatile } & \multicolumn{9}{|c|}{ Non-pulsatile } \\
\hline & 1 & 2 & & & & & 1 & 2 & & & & 3 & & & \\
\hline Experiment no. & 6 & 8 & 10 & 11 & 12 & 13 & 7 & 9 & 14 & 15 & 16 & 17 & 18 & 19 & 20 \\
\hline $\begin{array}{l}\text { Cerebral cortex } \\
\text { Frontal lobe } \\
\text { Parietal lobe } \\
\text { Occipital lobe } \\
\text { Temporal lobe } \\
\text { Hippocampus } \\
\text { Olfactory tract } \\
\text { Basal ganglia }\end{array}$ & $\begin{array}{l}\mathbf{0} \\
\mathbf{0} \\
\mathbf{0} \\
\mathbf{0} \\
\mathbf{0} \\
\mathbf{0}\end{array}$ & $\begin{array}{l}0 \\
0 \\
0 \\
0 \\
0 \\
0\end{array}$ & $\begin{array}{l}0 \\
0 \\
0 \\
0 \\
0 \\
0\end{array}$ & $\begin{array}{l}\mathbf{0} \\
0 \\
0 \\
0 \\
0 \\
0\end{array}$ & $\begin{array}{l}\mathbf{0} \\
\mathbf{0} \\
\mathbf{0} \\
\mathbf{0} \\
\mathbf{0} \\
\mathbf{0}\end{array}$ & $\begin{array}{l}\mathbf{0} \\
\mathbf{0} \\
\mathbf{0} \\
\mathbf{0} \\
\mathbf{0} \\
\mathbf{0}\end{array}$ & $\begin{array}{l}0 \\
0 \\
0 \\
0 \\
0 \\
0\end{array}$ & $\begin{array}{l}0 \\
0 \\
0 \\
0 \\
0 \\
0\end{array}$ & $\begin{array}{l}\mathbf{0} \\
\mathbf{0} \\
\mathbf{0} \\
\mathbf{0} \\
\mathbf{0} \\
\mathbf{0}\end{array}$ & $\begin{array}{l}0 \\
0 \\
0 \\
0 \\
0 \\
0\end{array}$ & $\begin{array}{l}0 \\
0 \\
0 \\
0 \\
0 \\
0\end{array}$ & $\begin{array}{l}0 \\
0 \\
0 \\
0 \\
0 \\
0\end{array}$ & $\begin{array}{l}0 \\
0 \\
0 \\
0 \\
0 \\
0\end{array}$ & $\begin{array}{l}0 \\
0 \\
0 \\
0 \\
0 \\
0\end{array}$ & $\begin{array}{l}0 \\
0 \\
0 \\
0 \\
0 \\
0\end{array}$ \\
\hline $\begin{array}{l}\text { Caudate nucleus } \\
\text { Putamen } \\
\text { Globus pallidus } \\
\text { Amygdaloid nuciei } \\
\text { Mid-brain }\end{array}$ & $\begin{array}{l}\mathbf{0} \\
\mathbf{0} \\
\mathbf{0} \\
\mathbf{0}\end{array}$ & $\begin{array}{l}\mathbf{0} \\
\mathbf{0} \\
\mathbf{0} \\
\mathbf{0}\end{array}$ & $\begin{array}{l}0 \\
0 \\
0 \\
0\end{array}$ & $\begin{array}{l}\mathbf{0} \\
0 \\
0 \\
0\end{array}$ & $\begin{array}{l}\mathbf{0} \\
\mathbf{0} \\
\mathbf{0} \\
\mathbf{0}\end{array}$ & $\begin{array}{l}\mathbf{0} \\
\mathbf{0} \\
\mathbf{0} \\
\mathbf{0}\end{array}$ & $\begin{array}{l}\mathbf{0} \\
\mathbf{0} \\
\mathbf{0} \\
\mathbf{0}\end{array}$ & $\begin{array}{l}\mathbf{0} \\
\mathbf{0} \\
\mathbf{0} \\
\mathbf{0}\end{array}$ & $\begin{array}{l}\mathbf{0} \\
\mathbf{0} \\
\mathbf{0} \\
\mathbf{0}\end{array}$ & $\begin{array}{l}0 \\
0 \\
0 \\
0\end{array}$ & $\begin{array}{l}0 \\
0 \\
0 \\
0\end{array}$ & $\begin{array}{l}0 \\
0 \\
0 \\
0\end{array}$ & $\begin{array}{l}0 \\
0 \\
0 \\
0\end{array}$ & $\begin{array}{l}0 \\
0 \\
0 \\
0\end{array}$ & $\begin{array}{l}0 \\
0 \\
0 \\
0\end{array}$ \\
\hline $\begin{array}{l}\text { Claustrum } \\
\text { Anterior nucleus } \\
\text { Dorsal parietal nucleus } \\
\text { Trigeminal nucleus } \\
\text { Reticular nuclei } \\
\text { Dorsal vagal nucleus } \\
\text { Inferior olivary nucleus } \\
\text { Substantia nigra } \\
\text { Cerebellum }\end{array}$ & $\begin{array}{l}\mathbf{0} \\
\mathbf{0} \\
\mathbf{0} \\
\mathbf{0} \\
\mathbf{0} \\
\mathbf{0} \\
\mathbf{0} \\
\mathbf{0}\end{array}$ & $\begin{array}{l}\mathbf{0} \\
\mathbf{0} \\
\mathbf{0} \\
\mathbf{0} \\
\mathbf{0} \\
\mathbf{0} \\
\mathbf{0} \\
\mathbf{0}\end{array}$ & $\begin{array}{l}\mathbf{0} \\
\mathbf{0} \\
\mathbf{0} \\
\mathbf{0} \\
\mathbf{0} \\
\mathbf{0} \\
\mathbf{0} \\
\mathbf{0}\end{array}$ & $\begin{array}{l}\mathbf{0} \\
0 \\
0 \\
0 \\
0 \\
0 \\
0 \\
0\end{array}$ & $\begin{array}{l}\mathbf{0} \\
\mathbf{0} \\
\mathbf{0} \\
\mathbf{0} \\
\mathbf{0} \\
\mathbf{0} \\
\mathbf{0} \\
\mathbf{0}\end{array}$ & $\begin{array}{l}\mathbf{0} \\
\mathbf{0} \\
\mathbf{0} \\
\mathbf{0} \\
\mathbf{0} \\
\mathbf{0} \\
\mathbf{0} \\
\mathbf{0}\end{array}$ & $\begin{array}{l}0 \\
0 \\
0 \\
0 \\
0 \\
0 \\
0 \\
0\end{array}$ & $\begin{array}{l}\mathbf{0} \\
0 \\
0 \\
0 \\
\mathbf{0} \\
\mathbf{0} \\
\mathbf{0} \\
\mathbf{0}\end{array}$ & $\begin{array}{l}\mathbf{0} \\
0 \\
0 \\
0 \\
0 \\
0 \\
0 \\
0\end{array}$ & $\begin{array}{l}0 \\
0 \\
0 \\
0 \\
0 \\
0 \\
0 \\
0\end{array}$ & $\begin{array}{l}\mathbf{0} \\
0 \\
0 \\
0 \\
0 \\
0 \\
0 \\
0\end{array}$ & $\begin{array}{l}0 \\
0 \\
0 \\
0 \\
0 \\
0 \\
0 \\
0\end{array}$ & $\begin{array}{l}0 \\
0 \\
0 \\
0 \\
0 \\
0 \\
0 \\
0\end{array}$ & $\begin{array}{l}0 \\
0 \\
0 \\
0 \\
0 \\
0 \\
0 \\
0\end{array}$ & $\begin{array}{l}0 \\
0 \\
0 \\
0 \\
0 \\
0 \\
0 \\
0\end{array}$ \\
\hline $\begin{array}{l}\text { Purkinje cells } \\
\text { Fastigial nucleus } \\
\text { Dentate nucleus }\end{array}$ & $\begin{array}{l}\mathbf{0} \\
\mathbf{0} \\
\mathbf{0}\end{array}$ & $\begin{array}{l}\mathbf{0} \\
\mathbf{0} \\
\mathbf{0}\end{array}$ & $\begin{array}{l}\mathbf{0} \\
\mathbf{0} \\
\mathbf{0}\end{array}$ & $\begin{array}{l}\mathbf{0} \\
\mathbf{0} \\
\mathbf{0}\end{array}$ & $\begin{array}{l}\mathbf{0} \\
\mathbf{0} \\
\mathbf{0}\end{array}$ & $\begin{array}{l}\mathbf{0} \\
\mathbf{0} \\
\mathbf{0}\end{array}$ & $\begin{array}{l}\mathbf{0} \\
\mathbf{0} \\
\mathbf{0}\end{array}$ & $\begin{array}{l}3 \\
0 \\
0\end{array}$ & $\begin{array}{l}\mathbf{0} \\
\mathbf{0} \\
\mathbf{0}\end{array}$ & $\begin{array}{l}\mathbf{0} \\
\mathbf{0} \\
\mathbf{0}\end{array}$ & $\begin{array}{l}3 \\
0 \\
0\end{array}$ & $\begin{array}{l}\mathbf{0} \\
\mathbf{0} \\
\mathbf{0}\end{array}$ & $\begin{array}{l}3 \\
\mathbf{0} \\
\mathbf{0}\end{array}$ & $\begin{array}{l}\mathbf{0} \\
\mathbf{0} \\
\mathbf{0}\end{array}$ & $\begin{array}{l}\mathbf{0} \\
\mathbf{0} \\
\mathbf{0}\end{array}$ \\
\hline
\end{tabular}

$0=$ none; $1=a$ few; $2=$ several; $3=$ many. 


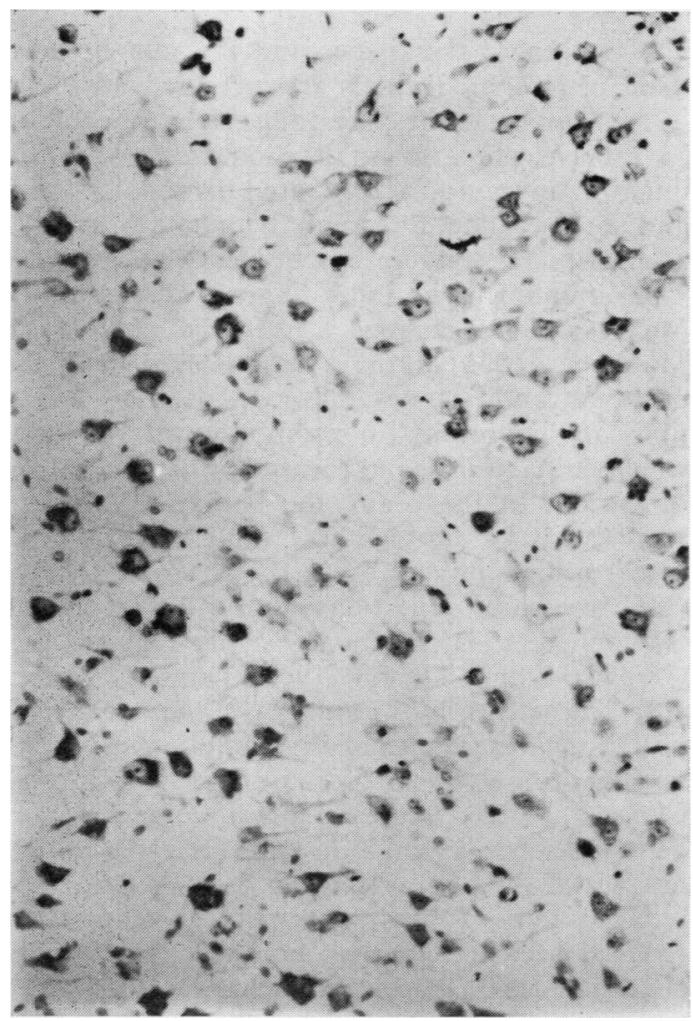

FIG. 8. Margin of a focal lesion in dog cerebral cortex showing pale-staining nerve cells (right) and normal nerve cells (left); 3 hours' non-pulsatile flow (haematoxylin and van Gieson $\times 100$ ).

PULSATILE EXPERIMENT NUMBER

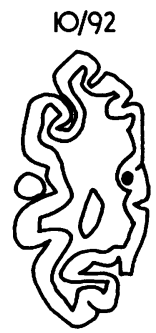

left posterior ectosylvion gyrus

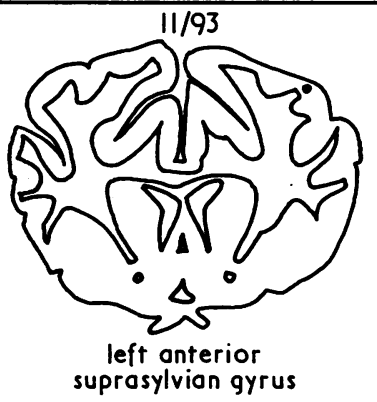

FIG. 9. Location of focal lesions in dog brain immediately following extracorporeal circulation.

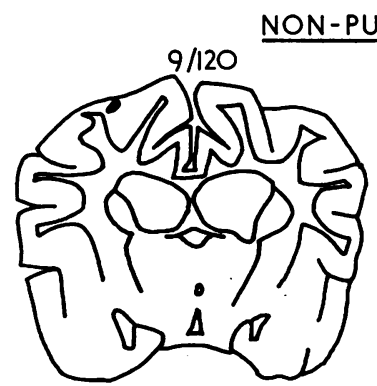

right medial suprosylvion gyrus

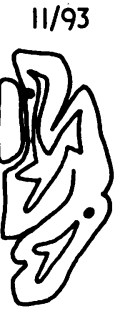

left lingual gyrus and left posterior suprosylvion gyrus

$9 / 120$

$9 / 120$

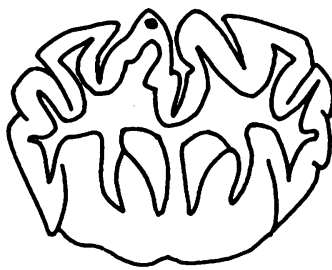

precuneus 
A haemorrhage occupied much of the adenohypophysis and arachnoid space of dog 15/85 but the neurohypophysis was spared.

Perfusion-fixation tended to be less successful after non-pulsatile than after pulsatile experiments, judged by the macroscopic appearance of the brain (Table I). An attempt to improve the quality of fixation following non-pulsatile extracorporeal circulation was made in experiment 20/149 by using 5 litres of fixative instead of 2 litres. Perfusion-fixation was judged to be excellent in this experiment but some ICC was found in microscope sections.

In Table IV, some physiological variables measured during three-hour pulsatile (four experiments) and non-pulsatile (seven experiments) perfusions are compared. Peripheral vascular resistance (PVR) was calculated by the formula:

$$
\text { PVR (units) }=\frac{\mathrm{AP}(\mathrm{mmHg})-\mathrm{VP}(\mathrm{mmHg})}{\text { Pump flow rate }(\mathrm{ml} / \mathrm{sec})}
$$

Significantly higher values of AP and PVR were obtained during non-pulsatile perfusions. The $\mathrm{PACO}_{2}$ was higher during pulsatile perfusions though the difference was not statistically significant.

\section{DISCUSSION}

A strong case can be made in favour of using pulsatile blood flow for extracorporeal circulation. The case can be stated in teleological, theoretical, clinical, and experimental terms.

The teleological evidence has been presented by Wilkens, Regelson, and Hoffmeister (1962) who correlated the evolutionary transition from aquatic to terrestrial environments with the development of high blood pressures and pulse pressures in vertebrates. Unfortunately, the authors selected specialized representatives of the various classes for their schema of cardiac evolution. However, there may be some significance in the systolic pressure difference of $300 \%$ between frog and pigeon and a $400 \%$ higher pulse-pressure in the pigeon. By these devices, the supply of nutrients and oxygen to the tissues and the rate of movement of interstitial fluids are increased.

Two important features of vertebrate evolution have been compartmentalization of the heart culminating in the four-chambered mammalian heart, and the abandonment of lymphatic hearts as arterial pulse pressure amplitudes were increased. The monumental and diligent researches of McMaster and Parsons (1938) and Parsons and McMaster (1938) on the spread of dyes in isolated, perfused rabbit ears established that arterial pulsations are important for promoting the movement of interstitial fluids, and for the formation and flow of lymph. In the brain, the lymphatic system is represented by the cerebral ventricles containing cerebrospinal fluid (CSF). The arterial origin of CSF pressure pulsations is well documented (O'Connell, 1943; Bering, 1955; de Langen, 1959; Greenfield and Tindall, 1965; Dunbar, Guthrie, and Karpell, 1966; Laitinen, 1968). If arterial pulsations are important in promoting the formation and flow of interstitial fluids, lymph, and CSF, a theoretical case for pulsatile perfusion can be established. During non-pulsatile perfusions the interstitial fluid pressure will rise because of the reduced rate of lymph or CSF movement. The reduced pressure gradient between the capillaries and interstitial spaces will decrease the rate of $\overrightarrow{\vec{B}}$ transudation across the capillary wall, but the $\frac{3}{3}$ interstitial fluid pressure will continue to increase because of the high oncotic pressure of the tissue fluid. Eventually the interstitial fluid pressure may exceed capillary pressure and the capillaries will collapse. Thereafter, blood may flow only in $\underset{x}{\stackrel{\Xi}{\Perp}}$ microcirculatory shunts, as observed by Takeda $\dot{\circ}$ (1960). A mechanism such as this could explain the numerous collapsed capillaries and the diffuse 8 ICC found in our dog brains and in the brains of open-heart surgery patients (Björk and Hultquist, 윽 1960 ; Silverstein, Jacobson, Kreel, and Krieger, 1960 ; Fowler, Kavan, and Walter, 1962 ; Brierley, 1963, 1967 ; Javid et al., 1969). Similar results, but different conclusions, were reported following o

T A B L E I V

STATISTICAL COMPARISONS OF PHYSIOLOGICAL VARIABLES DURING 3-HOUR PULSATILE AND NON-PULSATILE

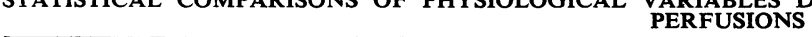

\begin{tabular}{|c|c|c|c|c|c|c|}
\hline \multirow{2}{*}{ Physiological Variable } & \multicolumn{2}{|c|}{ Pulsatile } & \multicolumn{2}{|c|}{ Non-pulsatile } & \multicolumn{2}{|c|}{ Student's $t$ Probability } \\
\hline & $\overline{\mathbf{x}}$ & d & $\overline{\mathbf{x}}$ & d & $t$ & $\mathbf{P}$ \\
\hline $\begin{array}{l}\text { AP (mmHg) } \\
\text { VP (cm Ho } \mathrm{H}_{2} \text { ) } \\
\text { Oesophageal temperature }\left({ }^{\circ} \mathrm{C}\right) \\
\text { Blood flow rate }(\mathrm{ml} / \mathrm{kg} / \mathrm{min}) \\
\text { PACO }_{2} \text { (mmHg) } \\
\text { PVR (units) }\end{array}$ & $\begin{array}{r}39 \cdot 811 \\
7 \cdot 394 \\
30 \cdot 124 \\
56 \cdot 372 \\
46 \cdot 120 \\
2 \cdot 584\end{array}$ & $\begin{array}{r}6 \cdot 027 \\
3 \cdot 502 \\
0 \cdot 609 \\
6 \cdot 002 \\
10 \cdot 370 \\
0 \cdot 950\end{array}$ & $\begin{array}{r}76 \cdot 744 \\
7 \cdot 891 \\
29 \cdot 601 \\
64 \cdot 406 \\
35 \cdot 380 \\
6 \cdot 013\end{array}$ & $\begin{array}{l}6 \cdot 450 \\
2 \cdot 420 \\
0 \cdot 757 \\
2 \cdot 995 \\
4.977 \\
0 \cdot 595\end{array}$ & $\begin{array}{l}8 \cdot 942 \\
0 \cdot 253 \\
1 \cdot 157 \\
2 \cdot 697 \\
1 \cdot 565 \\
6 \cdot 710\end{array}$ & $\begin{array}{l}<0.001 \\
>0.100 \\
>0.100 \\
<0.020 \\
<0.100 \\
<0.001\end{array}$ \\
\hline
\end{tabular}


dog experiments by Schweikert and Sickinger (1960), Almond et al. (1964), Connolly, Roy, Guernsey, and Stemmer (1965), Miller, Hallaba, and Steegmann (1965), and Steegmann and Miller (1965).

The theoretical case for pulsatile blood flow is strengthened by the analysis of haemodynamic energy performed by Shepard, Simpson, and Sharp (1966), who also verified the analysis both experimentally and clinically. This analysis predicts higher mean flow rates for pulsatile flow compared with non-pulsatile flow at equal mean arterial blood pressures. The mechanism may depend upon the reflexogenic activity of the carotid baroreceptors which respond to a change from pulsatile to non-pulsatile blood flow in the same way as they respond to sudden hypotension, that is by reflex vasoconstriction. It is well known that the carotid baroreceptors do respond to both static and pulsatile components of total energy (Ead, Green, and Neil, 1952 ; Filistovich, Gero, and Gerova, 1966 ; Giron, Birtwell, Soroff, and Deterling, 1966 ; Koushanpour and McGee, 1969; Soroff et al., 1969) and the effect may be augmented by the release of vasoconstrictive humoral agents during non-pulsatile blood flows (Kohlstaedt and Page, 1940; Many, Soroff, Birtwell, and Deterling, 1968a: Many et al., 1968b ; Many et al., 1969). Reflex or humoral vasoconstriction could explain the higher PVRs in our dogs perfused with non-pulsatile flow compared with those perfused with pulsatile flow.

Pulsatile blood flow confers the advantages of agitating the diffusion shells of metabolic substances in the tissues and improving gas exchange. Metabolic studies have shown that the rate of tissue respiration is higher during pulsatile than during non-pulsatile perfusion (Nonoyama, 1960 ; Ida, 1962 : Shepard and Kirklin, 1969 ; Trinkle, Helton, Wood, and Bryant, 1969). Pulsatile blood flow may be associated with a lower 'critical closing pressure' (Burton, 1954) than non-pulsatile flow because blood flow in capillaries will occur during peak systole even when the mean blood pressure is slightly below the "critical closing pressure' for non-pulsatile flow.

Non-pulsatile flow is associated with a depression of kidney function not found during pulsatile perfusion (Hooker, 1910 ; Gesell, 1913 ; Judson and Rausch, 1957 ; Many et al., 1967 ; Many et al., 1968a, 1968b; Jacobs et al., 1969; Paquet, 1969); moderate to severe hydropic degeneration of kidney tubules is found only after non-pulsatile perfusion (Dalton, McCarty, Woodward, and Barila, 1965a ; Dalton, Mosley, Woodward, and Barila, 1965b); and unilateral renal artery depulsation results in increases in juxtaglomerular cell granulation and in tissue renin content that correlate with decreases in sodium and water excretion (Many et al., 1969).

In contradiction, Selkurt (1951) found no changes in plasma flow or filtration rate in kidneys perfused with a wide range of pulse pressure amplitudes ; depulsation of dog renal arteries produced no significant changes in the excretion rates of water and electrolytes, or in the clearances of inulin and paraminohippurate (Goodyer and Glenn, 1951); the increase in peripheral vascular resistance alleged to be associated with nonpulsatile perfusion (Nonoyama, 1960; Takeda, 1960 ; Nakayama et al., 1963 ; Burns, McInnes, and Mandelbaum, 1965 ; Mandelbaum et al., 1965 ; Mandelbaum and Burns, 1965 ; Jacobs et al., 1969) was not produced during perfusions of the kidneys by Ritter (1952) and by Paquet (1965) ; Randall and Stacy (1956) detected only non-significant differences in blood flows in the hind legs of dogs perfused with pulsatile and non-pulsatile blood flows at equal mean blood pressures; and turbulence and vorticity are more apparent in pulsatile than in non-pulsatile flows (Attinger, 1964).

Possibly the most influential barrier to the adoption of pulsatile flow for extracorporeal circulation has been the researches of Wesolowski, Fisher, and Welch (1953). They found that nonpulsatile right-heart bypass was compatible with normal respiratory functions and no permanent alterations in circulatory dynamics. This was later supported by Clarke, Kahn, Dufek, and Sloan (1968) and by Wemple, Mockros, and Lewis (1969). In the same series of experiments, Wesolowski produced preliminary evidence that pulsatile perfusion caused less systemic hypotension than nonpulsatile flow, but the point was subsequently negated by their finding no significant differences in haemodynamics, kidney function, vascular tone, recovery rate, blood indices, and organ histology between dogs perfused with pulsatile and nonpulsatile flows (Wesolowski, Sauvage, and Pinc, 1955). The criticism made against these results is that the use of high flow rates $(130 \mathrm{ml} / \mathrm{kg}$ per minute) by Wesolowski probably obviated the differences (Ogata et al., 1960).

Therefore, the evidence in favour of pulsatile perfusion is strong. The confusion that remains may be largely due to the failure of some authors to define their concept of 'pulsatile blood flow'. Few reports provide blood pressure or flow records, and it is clear that some of the so-called 'pulsatile' pumps deliver sinusoidal pressure and flow wave-forms that are totally different from those generated by the heart. It is our opinion 
that a rapid upstroke on the phasic pressure waveform is necessary to maximize haemodynamic energy, that is to maximize the difference between mean blood pressure and 'energy equivalent pressure' (Shepard et al., 1966).

A further cause of confusion may be the variety of investigative techniques employed and the choice of different recovery durations. The brain is the organ most susceptible to hypoxia and ischaemia but the nerve cell changes found in our dogs were minor and possibly reversible. These changes closely resemble the artefacts produced by inadequate fixation and we have taken great care to avoid this complication. However, perfusionfixation appeared to be less efficient after nonpulsatile than after pulsatile perfusions. The grade of fixation correlated poorly with the incidence of nerve cell changes and cell changes were found even in well fixed brains. Therefore, it appears that this was not an important mechanism in our experiments, but it is possible that nerve cell changes caused by non-pulsatile blood flow were augmented by fixation artefacts but were not entirely attributable to them.

Our results can be criticized for three other reasons. First, blood flow in the aorta was retrograde during non-pulsatile and prograde during pulsatile perfusions. Turbulence, cavitation, and venturi effects may be produced at branch orifices by retrograde blood flow, particularly in the splanchnic region where the arteries arise at acute angles from the aorta. However, this may not occur at the aortic arch where the angle subtended between the branches and the aorta is approximately $90^{\circ}$. Therefore, cerebral perfusion is unlikely to be affected by retrograde blood flow in the aorta. This conclusion is supported by measurements made on squirrel monkeys by Lees et al., 1971.

Secondly, although $\mathrm{PACO}_{2}$ was controlled by variations in the respiratory gas mixture, it is clear that this control was not adequate because $\mathbf{P A C O}_{2}$ was usually higher during pulsatile than during non-pulsatile perfusions (Table IV). This difference was not statistically significant, but the failure to establish a statistical relationship does not prove the absence of one, so that our results may be attributed to higher cerebral blood flows caused by $\mathrm{CO}_{2}$ vasodilatation during pulsatile perfusions (Harper, 1965 ; Zwetnow, 1968). However, in our experiments, the cerebral blood vessels were probably dilated in both groups of dogs by halothane anaesthesia (Christensen, Høedt-Rasmussen, and Lassen, 1967), and the effect of $\mathrm{CO}_{2}$ may have been reduced by the general systemic hypotension
(Zwetnow, 1968). Furthermore, in the non-pulsatile $\overrightarrow{\overrightarrow{\mathrm{F}}}$ group, tissue hypoxia would be liable to increaseo cerebral blood flow (Pontén and Siesjö, 1965).흐 Finally, the mean arterial blood pressure waso higher in the non-pulsatile group, so that the effectsథ of $\mathrm{CO}_{2}$ in cerebral blood flow must have been minimal.

The third criticism is more refractory. This is $\vec{\circ}$ that the nerve cell changes found in non-pulsatile $\vec{\omega}$ experiments may have been caused by bloodo sludging in the microcirculation as a result of $\overrightarrow{\vec{x}}$ increased blood viscosity. There is no experimentali evidence for this conclusion except that sequestered ${ }_{\omega}$ red cells were seen in some capillaries in the brains $w$ of dogs subjected to non-pulsatile extracorporealor circulation. Blood viscosity may have been in-o creased by plasma protein denaturation, which_ was not measured, and/or by haemolysis, which 3 in in vitro tests was found to be 30 times higher with a DeBakey roller pump than with our new $\overrightarrow{0}$ pulsatile pump.

Thus, the preferred conclusion is that early diffuse nerve cell changes are to be attributed too non-pulsatile perfusion, but retrograde blood flow, lower arterial carbon dioxide tensions, higher rateso of haemolysis, and interference with perfusion- $\frac{0}{D}$ fixation by microcirculatory changes resulting from 0 non-pulsatile perfusion are admitted as complicat-ö ing factors. However, it may safely be concluded 3 that tissue perfusion was improved by using the Morton-Keele pulsatile pump when compared with? perfusions employing DeBakey roller pumps.

Focal lesions were evident at a surprisingly early을 stage of these experiments. They were probablyx caused by cerebral emboli. In vitro tests performed윽 in our laboratories indicate that gas microbubbles. liberated during rewarming and aggregates of blood cells are possible causes of cerebral embolism.

The opinions expressed above have been influ- $\rightarrow$ enced by some other experiments performed in our․ㅡㄹ. laboratories. These include electron microscopen examinations of the brain and automated nerve cell counts following extracorporeal circulation in dogs, brain histology of dogs allowed to recoverw after perfusions, and in vitro studies using an ultrasonic blood flow detector to detect gas microe bubbles and cellular aggregates in circulating blood. The results of these experiments will be? submitted for publication shortly.

It is a pleasure to acknowledge the assistance of ourd colleagues in the W. E. Dunn Unit of Cardiology and the cardiac surgery team of the North Staffordshire Royal Infirmary, and to thank members of the Departments of Physiology and Pathology at the University? 
of Birmingham for valuable help. The pulsatile pump was constructed by Messrs. P. Morton and G. Salwey of G.E.C. Power Engineering Ltd. and extensively rebuilt to precision standards in the Keele University Workshops under the supervision of Mr. H. Wardell. Professor A. R. Gemmell provided the facilities of the Biology Department. One of us (J.M.S.) was in receipt of a research grant from the Birmingham Regional Hospital Board.

\section{REFERENCES}

Almond, C. H., Jones, J. C., Snyder, H. M., Grant, S. M., and Meyer, B. W. (1964). Cooling gradients and brain damage with deep hypothermia. $J$. thorac. cardiovasc. Surg., 48, 890.

Attinger, E. O. (1964). Flow patterns and vascular geometry. In: Pulsatile Blood Flow, edited by E. O. Attinger, pp. 179-200 McGraw-Hill, New York, Toronto and London.

Bering, E. A. (1955). Choroid plexus and arterial pulsation of cerebrospinal fluid. Arch. Neurol. Psychiat. (Chic.), 73, 165.

Björk, V. O., and Hultquist, G. (1960). Brain damage in children after deep hypothermia for open-heart surgery. Thorax, 15, 284.

Brierley, J. B. (1963). Neuropathological findings in patients dying after open-heart surgery. Thorax, 18, 291.

(1967). Brain damage complicating open-heart surgery: a neuropathological study of 46 patients. Proc. roy. Soc: Med., 60, 858.

Brown, A. W., and Brierley, J. B. (1968). The nature, distribution and earliest stages of anoxic-ischaemic nerve cell damage in the rat brain as defined by the optical microscope. Brit. J. exp. Path., 49, 87.

Burns, W. H., McInnes, A. G. P., and Mandelbaum, I. (1965). Hemodynamic studies with a new pulsatile pump. Trans. Amer. Soc. artif. intern. Org., 11, 65.

Burton, A. C. (1954). Relation of structure to function of the tissues of the wall of blood vessels. Physiol. Rev., 34, 619.

Christensen, M. S., Høedt-Rasmussen, K., and Lassen, N. A. (1967). Cerebral vasodilatation by halothane anaesthesia in man and its potentiation by hypotension and hypercapnea. Brit. J. Anaesth., 39, 927.

Clarke, C. P., Kahn, D. R., Dufek, J. H., and Sloan, H. (1968). The effects of nonpulsatile blood flow on canine lungs. Ann. thorac. Surg., 6, 450.

Connolly, J. E., Roy, A., Guernsey, J. M., and Stemmer, E. A. (1965). Bloodless surgery by means of profound hypothermia and circulatory arrest. Effect on brain and heart. Ann. Surg., 162, 724.

Dalton, M. L., McCarty, R. T., Woodward, K. E., and Barila, T. G. (1965a). The army artificial heart pump. II. Comparison of pulsatile and nonpulsatile flow. Surgery, 58, 840.

, Mosley, E. C., Woodward, K. E., and Barila, T. G. (1965b). The effect of pulsatile flow on renal blood flow during extracorporeal circulation. J. Surg. Res., 5, 127.

DeBakey, M. (1934). A simple continuous-flow blood transfusion instrument. New Orleans med. surg. J., 87, 386. de Langen, C. D. (1959). Die klinische Bedeutung der Pulsdruckamplitude. Münch. med. Wschr., 101, 2132.

Drew, C. E. (1961). Profound hypothermia in cardiac surgery. Brit. med. Bull., 17, 37.

Dunbar, H. S., Guthrie, T. C., and Karpell, B. (1966). A study of the cerebrospinal fluid pulse wave. Arch. Neurol. (Chic.), 14, 624.

Ead, H. W., Green, J. H., and Neil, E. (1952). A comparison of the effects of pulsatile and non-pulsatile blood flow through the carotid sinus on the reflexogenic activity of the sinus baroreceptors in the cat. J. Physiol. (Lond.), 118, 509.

Filistovich, V. I., Gero, Y. I., and Gerova, M. A. (1966). The significance of the amplitude of pressure pulse oscillations for the activity of the carotid sinus baroreceptors (in Russian). Fiziol. Zh. (Mosk.), 52, 874.

Fowler, W. M., Kavan, E. M., and Walter, R. D. (1962). Open-heart surgery. Neurologic findings and electroencephalographic patterns before, during, and after open-heart surgery (two-year follow-up). Amer. J. Dis. Child., 104, 131.

Gesell, R. A. (1913). On the relation of pulse pressure to renal secretion. Amer. J. Physiol., 32, 70.

Giron, F., Birtwell, W. C., Soroff, H. S., and Deterling, R. A. (1966). Hemodynamic effects of pulsatile and nonpulsatile flow. Arch. Surg., 93, 802.

Goodyer, A. V. N., and Glenn, W. W. L. (1951). Relation of arterial pulse pressure to renal function. Amer. J. Physiol., 167, 689.

Greenfield, J. G., and Tindall, G. T. (1965). Effect of acute increase in intracranial pressure on blood flow in the internal carotid artery of man. J. clin. Invest., 44, 1343.

Harper, A. M. (1965). The inter-relationship between $\mathrm{aPCO}_{2}$ and blood pressure in the regulation of blood flow through the cerebral cortex. Acta neurol. scand., suppl. 14, p. 94.

Hooker, D. R. (1910). A study of the isolated kidney-the influence of pulse pressure upon renal function. Amer. J. Physiol., 27, 24.

Ida, Y. (1962). Experimental studies on carbohydrate metabolism during heart lung bypass with special reference to a comparison of pulsatile flow with non-pulsatile flow. Arch. jap. Chir., 31, 181.

Jacobs, L. A., Klopp, E. H., Seamone, W., Topaz, S. R., and Gott, V. L. (1969). Improved organ function during cardiac bypass with a roller pump modified to deliver pulsatile flow. J. thorac. cardiovasc. Surg., 58, 703.

Javid, H., Tufo, H. M., Najafi, H., Dye, W. S., Hunter, J. A., and Julian, O. C. (1969). Neurological abnormalities following open-heart surgery. J. thorac. cardiovasc. Surg., 58, 502.

Judson, W. E., and Rausch, N. H. (1957). The effects of acute reduction of renal artery blood pressure on renal hemodynamics and excretion of electrolytes and water. J. Lab. clin. Med., 50, 923.

Kohlstaedt, K. G., and Page, I. H. (1940). The liberation of renin by perfusion of kidneys following reduction of pulse pressure. J. exp. Med., 72, 201.

Koushanpour, E., and McGee, J. P. (1969). Effect of mean pressure on carotid sinus baroreceptor response to pulsatile pressure. Amer. J. Physiol., 216, 599.

Laitinen, L. (1968). Origin of arterial pulsation of cerebrospinal fluid. Acta neurol. scand., 44, 168. 
Lees, M. H., Herr, R. H., Hill, J. D., Morgan, C. L., Ochsner, A. J., Thomas, C., and Van Fleet, D. L. (1971). Distribution of systemic blood flow of the rhesus monkey during cardiopulmonary bypass. $J$. thorac. cardiovasc. Surg., 61, 570.

Mandelbaum, I., Berry, J., Silbert, M., Burns, W. H., and Rothe, C. (1965). Regional blood flow during pulsatile and nonpulsatile perfusion. Arch. Surg., 91, 771.

- , and Burns, W. H. (1965). Pulsatile and nonpulsatile blood flow. J. Amer. med. Ass., 191, 657.

Many, M., Giron, F., Birtwell, W. C., Deterling, R. A., and Soroff, H. S. (1969). Effects of depulsation of renal blood flow upon renal function and renin secretion. Surgery, 66, 242.

- - Soroff, H. S., Birtwell, W. C., and Deterling, R. A. (1968a). Effects of bilateral renal artery depulsation on renin levels. Surg. Forum, 19, 387.

,,,--- Giron, F., Wise, H., and Deterling, R. A. (1967). The physiologic role of pulsatile and nonpulsatile blood flow. II. Effects on renal function. Arch. Surg., 95, 762.

, - - , Wise, H. M., and Deterling, R. A. (1968b). The physiologic role of pulsatile and nonpulsatile blood flow. III. Effects of unilateral renal artery depulsation. Arch. Surg., 97, 917.

McMaster, P. D., and Parsons, R. J. (1938). The effect of the pulse on the spread of substances through tissues. J. exp. Med., 68, 377.

Miller, D. R., Hallaba, M. A. S., and Steegmann, A. T. (1965). Effect of profound hypothermia with circulatory arrest in dogs. Special reference to changes in cerebrovascular permeability. Ann. Surg., 161, 272.

Nakayama, K., Tamiya, T., Yamamoto, K., Izumi, T., Akimoto, S., Hashizume, S., Iimori, T., Odaka, M., and Yazawa, C. (1963). High-amplitude pulsatile pump in extracorporeal circulation with particular reference to hemodynamics. Surgery, 54, 798.

Nonoyama, A. (1960). Hemodynamic studies on extracorporeal circulation with pulsatile and nonpulsatile blood flows. Arch. jap. Chir., 29, 1381.

O'Connell, J. E. A. (1943). The vascular factor in intracranial pressure and the maintenance of the cerebrospinal fluid circulation. Brain, 66, 204.

Ogata, T., Ida, Y., Nonoyama, A., Takeda, J., and Sasaki, H. (1960). A comparative study on the effectiveness of pulsatile and non-pulsatile blood flow in extracorporeal circulation. Arch. jap. Chir., 29, 59.

Paquet, K. J. (1965). Experimentelle Untersuchungen zur Funktion der isolierten Niere bei pulsatorischer und kontinuierlicher Perfusion. Bruns' Beitr. klin. Chir., 211, 463.

(1969). Hemodynamic studies on normothermic perfusion of the isolated pig kidney with pulsatile and nonpulsatile flows. J. cardiovasc. Surg., 10, 45.

Parsons, R. J., and McMaster, P. D. (1938). The effect of the pulse upon the formation and flow of lymph. J. exp. Med., 68, 353.

Pontén, U., and Siesjö, B. K. (1965). Brain tissue carbon dioxide changes and cerebral blood flow measurements. Acta neurol. scand., suppl. 14, p. 129.

Randall, J. E., and Stacy, R. W. (1956). Pulsatile and steady pressure-flow relations in the vascular bed of the hind leg of the dog. Amer.J. Physiol., 185, 351.
Ritter, E. R. (1952). Pressure flow relations in the kidney. Alleged effects of pulse pressure. Amer.J. Physiol., 168, 480.

Sanderson, J. M., Morton, P. G., Tolloczkio,T. S.,Vennart,T., $\frac{\bar{\sigma}}{\bar{\omega}}$ and Wright, G. A hydraulically activated pulsatile $\frac{\omega}{7}$ pump for use in extracorporeal circulation. Sub- $₫$ mitted for publication.

Schweikert, C. H., and Sickinger, K. (1960). Pathologischhistologische Befunde am Hund nach Anwendung eines $\vec{O}$ extrakorporalen Kreislaufes in Verbindung mit tiefer Hypothermie und temporärem Kreislaufstillstand. $\vec{\omega}$ Thoraxchirurgie, 8, 371 .

Selkurt, E. E. (1951). Effect of pulse pressure and mean $\overrightarrow{\vec{x}}$ arterial pressure modification on renal hemodynamics i and electrolyte and water excretion. Circulation, 4, 541. V

Shepard, R. B., and Kirklin, J. W. (1969). Relation of pulsatile flow to oxygen consumption and other variables during $\mathrm{N}$ cardiopulmonary bypass. J. thorac. cardiovasc. Surg., 58, 694.

—, Simpson, D. C., and Sharp, J. F. (1966). Energy equivalent pressure. Arch. Surg., 93, 730.

Silverstein, A., Jacobson, E., Kreel, I., and Krieger, H. P. (1960). Effects on the brain of extracorporeal circulation in open heart surgery. Neurology (Minneap.), 10, 987.

Soroff, H. S., Many, M., Birtwell, W. C., Giron, F., and Deterling, R. A. (1969). Hemodynamic effects of pulsatile and nonpulsatile blood flow. II. Selective depulsation of the aortic arch and brachiocephalic trunk. Arch. Surg., 98, 321.

Steegmann, A. T., and Miller, D. R. (1965). Some histopathologic aspects of cerebral injury in dogs subjected to profound hypothermia and circulatory arrest. Neurology (Minneap.), 15, 802.

Takeda, J. (1960). Experimental study of peripheral circulation during extracorporeal circulation, with a special reference to a comparison of pulsatile flow with nonpulsatile flow. Arch. jap. Chir., 29, 1407.

Trinkle, J. K., Helton, N. E., Wood, R. E., and Bryant, L. R. (1969). Metabolic comparison of a new pulsatile pump and a roller pump for cardiopulmonary bypass. J. thorac. cardiovasc. Surg., 58, 562.

Wemple, R. R., Mockros, L. F., and Lewis, F. J. (1969). Pulmonary function during pulsatile and nonpulsatile right heart bypass. J. thorac. cardiovasc. Surg., 57, 190.

Wesolowski, S. A., Fisher, J. H., and Welch, C. S. (1953). Perfusion of the pulmonary circulation by nonpulsatile flow. Surgery, 33, 370.

-, Sauvage, L. R., and Pinc, R. D. (1955). Extracorporeal circulation: the role of the pulse in maintenance of the systemic circulation during heart-lung bypass. Surgery, 37, 663 .

Wilkens, H., Regelson, W., and Hoffmeister, F. S. (1962). The physiologic importance of pulsatile blood flow. New Engl. J. Med., 267, 443.

Wright, G., and Sanderson, J. M. (1970). Improved method for fixation of dog brain by vascular perfusion. J. Path., 100, 295.

Zwetnow, N. (1968). Cerebral blood flow autoregulation to blood pressure and intracranial pressure variations. Scand. J. clin. Lab. Invest., 22, suppl. 102, VA. 